\title{
A comparison between the use of e- learning and Traditional education in working with groups and developing the skills of master students
}

\section{Wesam Mohamed Ibrahim (PhD)}

At group work Department Assistant professor

Faculty of Social work - Helwan University

\section{Hind Hassan Hammad (PhD)}

Assistant professor at group work Department

Faculty of Social work - Helwan University 
The Egyptian Journal of Social Work (EJSW) https://ejsw.journals.ekb.eg/e ISSN: 2356-9204 Vol 11, Issue.1, January2021 
The Egyptian Journal of Social Work (EJSW) https://ejsw.journals.ekb.eg/e

ISSN: 2356-9204

Vol 11, Issue.1, January2021

\section{Abstract:}

This study aims to make a comparison between the use of e-learning and traditional education in working with groups and developing the skills of master students. The study was applied to an intentional sample of (19) faculty members in working with groups department, faculty of social work, Helwan university and (25) students in the second level master stage, department of working with groups, faculty of social work, Helwan university. The study results indicated that there are statistically significant differences between the use of e-learning and traditional education in working with groups and developing the skills of master students as a whole in favor of elearning, from the viewpoint of faculty members significance at $(0.01)$,however, there are no statistical significant differences between the use of e-learning and traditional education in working with groups and developing the skills of master stage students as a whole in favor of e-learning from the viewpoint of master stage students. This indicates that master students are not aware of the importance and role of e-learning in developing skills as a whole. The study deduced that e-learning helps in developing the mental, professional and general skills of master's students.

\section{Key words:}

E-learning - traditional education - skills

\section{Introduction:}

The world witnesses a scientific and technological revolution with various dimensions that affect all aspects of human activities, especially, the aspects related to education. (Mahdi, 2006, p. 65-90).

The developments in the areas related to information technology have led to global transformations that have affected all educational processes, especially teaching and learning methods. These transformations have led to the emergence of modern mechanisms in methods, knowledge acquisition, and skills. Also, it became easy to employ information technology that transcends time and space constraints. (Hassan, 2009, p. 140)

E-learning is one of the best aspects that modern technology offers in the field of education. As a result of the growth in the use of the internet and availability of information and knowledge, the students were able to learn in different ways that were not available in the past. Besides, it creates cooperation and interaction among the students and their professors at any time and in any place. On this basis, e-learning grew rapidly in the field of higher education as this type of education led to a decrease in costs, flexibility in learning, and 
The Egyptian Journal of Social Work (EJSW) https://ejsw.journals.ekb.eg/e

ISSN: 2356-9204

Vol 11, Issue.1, January2021

increased the number of students enrolled in various educational programs. Also, e-learning plays a prominent role in scaffolding students to complete their studies and gain new knowledge without being obliged to attend traditional classes. Subsequently, students can develop their educational capabilities.(Al-ghadian, 2012, pp.423-454).

In this regard, the study of Bartley \& Golic (2004), aimed at evaluating the cost and effectiveness of online and face-to-face instruction showed that online instruction is increasing and it has some benefits associated with its ability to consolidate education across geographical and time constraints. It presents a cost matrix tool by which the costs of online education can be tabulated and compared with the costs of traditional education

Despite the rapid developments in computer technologies and multiple electronic media, some Egyptian universities are unable to provide e-learning to students and use traditional teaching methods to display the content of educational courses accordingly. The traditional educational system includes several of elements, the most important of which are the professors, the students, the educational course, and teaching methods. These elements are no longer sufficient to build an effective e-learning system as the urgent need for e-learning programs that allow students to benefit from all elements of the educational process requires interaction with their professors and access to the required information in a little effort and a short time. In addition to the availability of basic computer skills for students, e-learning also enables the possibility of dealing with specialized software that helps students to easily realize the content of the educational material through explanatory films and various applied cases.(Al-Obaidi, 2015, p. 50)

The study of El-gamal (2014) that aimed at exploring the attitudes, perceptions towards the acceptance and readiness for elearning from a variety of perspectives, the degree of meeting local needs and the main factors of improvement that e-learning could provide to the Egyptian higher education sector were also investigated.

In addition, the statistics in the study of Malakhleh (2017), aimed at knowing the role of the e-learning of the human resources as a virtual technique which relies mainly on the electronic supports and communication network, partly to acquire skills, and obtaining the organizational knowledge in universities. The statistics indicated that the size of the e-learning market in the world is estimated with billions of dollars annually, concentrated in the United States of America with 
The Egyptian Journal of Social Work (EJSW) https://ejsw.journals.ekb.eg/e ISSN: 2356-9204

Vol 11, Issue.1, January2021

a ratio that ranges from $60 \%$ to $70 \%$. (Robyn \& Samarawickrema, 2004, pp. 214-240).

In this regard, e-learning has been categorized into two types, "synchronous education and asynchronous education". Synchronous education is a type of education through which a timetable is set for broadcasting educational lessons via the internet through audio and video lectures in which the course instructor delivers the educational subject and at the same time students listen and take all notes related to the curriculum including drawings and illustrative charts supported with the forms if necessary. The course professor can view his students and answer their questions at the same time. While the second type of e-learning is asynchronous education in which the educational course is downloaded from the university's website electronically at a time that suits students without committing to the date of the lecture. Thus, the students can listen to the lecture and view the written curriculum with diagrams and films that support students' understanding of the course. Also, the students can communicate with their professors through e-mails and online chat. (Al-Obaidi, 2015, p. 52)

The study of Mohsen (2014) aimed at investigating the attitudes of the academic supervisors at al-quads open university in Palestine towards the uses of the internet in education, indicated that there are statistically significant differences in the averages of academic supervisors' attitudes towards the internet and its uses in university education, where the degree of those trends reached $80.4 \%$ depending variables related to sex and experience at the university.

Also, the study of Oledzki (2005) that aimed at investigating the use of multimedia for e-learning, its results were used as a basis for more positive and potentially useful discussions about how multimedia can influence learning, namely, motivation caused by learning materials and its positive effect, using audio within multimedia learning and presentation, material \& teacher regulation, learning environments and the attitudes of participation toward multimedia material.

The study of Tedeschi (2009) aimed at implementing e-learning within campus institutions of higher education, resulted in increasing personal and institutional comprehension of e-learning through promoting the awareness of the pedagogical issues surrounding the elearning environment. This could in turn result in increasing full acceptance of e-learning, increasing support of policymakers, and encouraging faculty students who are new to the e-learning 
environment. The practical implications, understanding of the described motivations and inhibitors from the perspectives of camp faculty can provide administrators an "edge" in the implementation of e-learning programs. Thus, e-learning is one of the most important modern educational techniques, because it takes into account the individual differences between students as it works to train them on mental, professional, and general skills by using the educational methods in which the student relies on himself (self-learning) according to his capabilities, and learning style. (Johnson\& Aragon, 2002, pp. 227-252)

Social work is one of the professions that is concerned with the development of human resources. It aims at bringing about social changes in individuals, groups, and societies to create mutual adaptation between individuals and their environments, as well as contributing to the side of other disciplines in clarifying the changes that occur in society, which contributes to achieving the general and desired social goals. (Ahmed\& Dendrawy, 2012, pp. 211-273).

The study of (Al-Maser, 2014, pp. 243-282) aimed at measuring Female attitudes towards using e-learning in teaching social work according to the cognitive, emotional, and behavioral component. The study indicated that the attitudes of female students towards the use of e-learning in teaching social work at King Saud University came positive, with a high degree, and close to the three components of the trend scale.

The method of working with groups is one of the methods of the social service profession. It is affected by developments in the educational process. It is concerned with the development of its scientific and professional methods which include e-learning.

The study of Ahmed \& Dendrawy, (2012) aimed at identifying the viewpoint of faculty members and their assistants in activating e-learning and emphasizing the necessity of activating e-learning and its importance. The results of the study recommended that the curriculum contains the methods, methods of e-learning, how to use it in the curricula, and how to benefit from the latest developments in information technology during education. Through the previous presentation, the main study problem is determined as follows:

What is a comparison between the use of e-learning and traditional education in working with groups and developing the skills of master stage students? 
The Egyptian Journal of Social Work (EJSW) https://ejsw.journals.ekb.eg/e

ISSN: $2356-9204$

Vol 11, Issue.1, January2021

\section{Study Objectives:}

1) Determine a comparison between the use of e-learning and traditional education in working with groups and developing the skills of master's students.

2) Identify indicators that activate the use of e-learning for working with groups and developing the skills of master's students.

\section{Study hypotheses:}

First Hypothesis: There are statistically significant differences between the use of e-learning and traditional education in working with groups and developing mental skills for master students.

Second Hypothesis: There are statistically significant differences between the use of e-learning and traditional education in working with groups and developing professional skills of master students.

Third Hypothesis: There are statistically significant differences between the use of e-learning and traditional education in working with groups and developing general skills of master students.

\section{Study Concepts}

\section{1- E-Learning:}

E-Learning is defined as an educational system that provides educational programs for students at anytime and anywhere using interactive information and communication technologies to provide a multi-source in both synchronous and asynchronous learning environments based on self and interactive learning. (Al-Saqer, 2012, pp. 153-189)

E-Learning refers to an interactive system for distance education that is provided for students and depends on an integrated digital electronic environment that aims to build courses and communicate them via electronic networks. (Al-Hammadi, 2011, pp. 80-114)

E-Learning is also defined as one of the means that support the educational process and transforms it from the method of indoctrination to the method of creativity in which the latest methods in the field of education are employed through a full presentation of the curricula (educational content) through the International Information Network. (Alcomeshi, 2016, pp. 141-152).

The concept of e-Learning refers to a method used through electronic and computer media in the process of transferring and communicating information to students. (Hamida, 2015, pp. 198-210) 
The Egyptian Journal of Social Work (EJSW) https://ejsw.journals.ekb.eg/e

ISSN: 2356-9204

Vol 11, Issue.1, January2021

\section{2- Traditional education:}

Traditional education is defined as one of the types of education that aims to develop the knowledge side of the learner and depends on the method of lecture and presentation by the teacher and the role of the learner is limited to preserving and understanding the information after receiving it from the teacher without any effort to search and investigate and provide the educational content of the student in the form of a printed book. (Al-Turk, 2019, pp. 22-40)

Traditional education means using old teaching aids such as blackboard, pens, and textbook, and the teacher suffices to present his information regardless of mental, age level, and other characteristics of the learners.

Traditional education is also defined as the education system that the world has practiced since the beginning of the formal educational process until today. It depends on traditional culture which focuses on the production of knowledge and the use of traditional methods that rely on teaching curricula and content to students. (Othman, 2017, p. 40).

\section{3- Skills:}

A skill is defined as an accurate performance based on an understanding of what a person learns dynamic and mental while saving time, effort, and costs. (Hussein \& Ahmed, 2003, p. 310)

Skills mean the ingenuity of a person in using his knowledge, talents, and all his distinctive self-characteristics. (Habib, 2009,p. 149)

A skill is also defined as the ability of a professional practitioner to apply the goals of the profession and its impact on others with understanding, sound awareness and the ability to develop a professional relationship, observing and interpreting apparent and invisible behavior, ability to innovate solutions related to society's need. (Al-Sanhouri, 2007, p. 217)

The concept of skills refers to a balanced and acquired achievement ability that distinguishes the individual from others in carrying out special activities. (Shehata \& Al-Najjar, 2003, p. 302).

Such as mental skills refer to the ability of marshal attention to unleash the strength you already have. (Won, 2019, p.173)

Mental skills are also defined as the ability to deal with pressure is not about any physical or technical skill. In other words, it is psychological and about performing with freedom, dealing with distractions, regulating emotions, maintaining Self - confidence and trusting in the ability to deliver under pressure. (Jamie\&martin, 2014, p.9) 
The Egyptian Journal of Social Work (EJSW) https://ejsw.journals.ekb.eg/e

ISSN: 2356-9204

Vol 11, Issue.1, January2021

\section{Theoretical Guidelines of the Research: \\ Social Networking Theory:}

Social networking theory examines the patterns and characteristics of social connections and their relationship to the lives of individuals and the social organization. This theory uses a framework to study how people communicate with each other through computer networks. This includes network structure, network size, and network range, communication frequency between people, the density of interpersonal links, member characteristics, the network history, and available network resource. (Rahooma, 2002, p. 65 )

Network theory is based on a set of basic assumptions, most importantly include:

1) Network construction focuses on two areas. The first is global networking: a global interactive structure that includes topics of a global scope that do not belong to a particular ethnic group or minority, but all minorities and cultural disparities are embedded within the global network's interconnectedness. The second is the local social networks, showing the role of local groups that have created units within global interactions with a focus on local issues and policies. ( Robins \& Singer, 2008, pp. 387-420)

2) Information exchange allows people to update their beliefs about the costs and the benefits inherent in participation, and change their decisions. ( Sidney \& Schlozman \& Brady, 1995)

\section{Methodology:}

This study belongs to the pattern of comparative studies as they compare between the use of e-learning and the use of traditional education in working with groups and developing the skills of master stage students.

\section{Sample:}

The study was applied to an intentional sample of (19) faculty members (males and females) of working with groups department, faculty of social work, Helwan university and (25) students in the second level of master stage of working with groups department, faculty of social work, Helwan university.

The main justification behind using such an intentional sample is the availability of the sample and the exact specialization of this level.

\section{Tool :}

The tools of the study were as follows:

A. A questionnaire about using e-learning in working with groups and developing the skills of master stage students. 


\begin{tabular}{|cr|}
\hline The Egyptian Journal of Social Work (EJSW) https://ejsw.journals.ekb.eg/e \\
ISSN: 2356-9204 & Vol 11, Issue.1, January2021 \\
\hline
\end{tabular}

B. A questionnaire about using traditional education in working with groups and developing the skills of master stage students.

\section{The Design of the tool:}

A questionnaire about using of e-learning and traditional education in working with groups and developing the skills of master students was designed according to the following steps: researchers benefit from previous studies about e-learning and traditional education, the answer on the questionnaire items are determined as follows: totally agree $=5$ degrees, agree $=4$ degrees, almost Agree $=3$ degrees, not agree $=2$ degrees, not totally agree $=1$ degree. To calculate a comparison between the use of e-learning and traditional education in working with groups and developing the skills of master students, we used the arithmetic mean as shown in Table (3).

Table (1): Questionnaire about using e-learning in working with groups and develop the skills of master's students

\begin{tabular}{|l|l|c|}
\hline$S$ & Dimensions & $\begin{array}{l}\text { Number } \\
\text { Phrases }\end{array}$ \\
\hline 1 & $\begin{array}{l}\text { Use of e learning in working with groups and developing } \\
\text { mental skills of master stage students. }\end{array}$ & 20 \\
\hline 2 & $\begin{array}{l}\text { Use of e learning in working with groups and developing } \\
\text { professional skills of master stage students. }\end{array}$ & 20 \\
\hline 3 & $\begin{array}{l}\text { Use of e learning in working with groups and developing } \\
\text { general skills of master stage students. }\end{array}$ & 51 \\
\hline \multicolumn{2}{|c|}{ Total dimensions }
\end{tabular}

Table (2): Questionnaire about using traditional education in Working with groups and develop the skills of master stage students

\begin{tabular}{|l|l|c|}
\hline & Dimensions & Number of Phrases \\
\hline 1 & $\begin{array}{l}\text { Use of traditional education in working with groups } \\
\text { and developing mental skills of master stage students. }\end{array}$ & 20 \\
\hline 2 & $\begin{array}{l}\text { Use of traditional education in working with groups } \\
\text { and developing professional skills of master stage } \\
\text { students. }\end{array}$ & 20 \\
\hline 3 & $\begin{array}{l}\text { Use of traditional education in working with groups } \\
\text { and developing general skills of master stage students }\end{array}$ & 51 \\
\hline \multicolumn{2}{|l|}{ Total dimensions } & \\
\hline
\end{tabular}




\begin{tabular}{||c|c|}
\hline The Egyptian Journal of Social Work (EJSW) https://ejsw.journals.ekb.eg/e \\
ISSN: 2356-9204 & Vol 11, Issue.1, January2021 \\
\hline
\end{tabular}

- Assistant Professors constituted the highest percentage of faculty members, who teach master stage students, by $(52.6 \%)$. On the other hand, professors constituted the least percentage of faculty members, who teach master stage students, by (47.4\%). This confirms that the majority of the teaching staff who teach master stage students are assistant professors.

Table (5): Shows the primary data for the master stage students $(\mathrm{N}=\mathbf{2 5})$

\begin{tabular}{|l|l|l|l|}
\hline $\mathrm{S}$ & Age & $\mathrm{N}$ & $\%$ \\
\hline 1 & Less than 25 years & 9 & 36 \\
\hline 2 & $25-30$ years & 8 & 32 \\
\hline 3 & $30-40$ years & 8 & 32 \\
\hline $\mathrm{S}$ & Master's level & $\mathrm{N}$ & $\%$ \\
\hline 1 & Level 1 & - & - \\
\hline 2 & Level 2 & 25 & 100 \\
\hline 3 & Level 3 & - & - \\
\hline
\end{tabular}

The table above shows that:

- Master stage students who are less than 25 years old constitute $(36 \%)$ of the total number of students while master stage students whose age ranges from 25 to 30 years old constitute (32\%) of the total number of students. Similarly, are those whose age ranges from 30 to 40 years old. It shows that the majority of master students in the age group which is less than 25 years, and this indicates the speed of excellence and study in that stage which is characterized by a young age.

- The students who are studying in the second level of master stage constitute (100\%) of the total number of the students who are studying in the master stage.

\section{Results of the Field Study:}

\section{Testing the study hypotheses}

Table (6): Significant of the differences between the use of e-learning and traditional education in working with groups and developing the skills of master stage students as a whole

\begin{tabular}{|c|c|c|c|c|c|c|c|c|}
\hline S & Category & $\begin{array}{l}\text { Type of } \\
\text { education }\end{array}$ & Sample & (SD) & Mean & $\begin{array}{l}\mathrm{T} \\
\text { value }\end{array}$ & DF & Sig \\
\hline \multirow[b]{2}{*}{1} & \multirow{2}{*}{$\begin{array}{l}\text { faculty } \\
\text { members }\end{array}$} & E-learning & 19 & 15.59 & 221.4 & \multirow[b]{2}{*}{$* * 4.26$} & \multirow[b]{2}{*}{18} & \multirow{2}{*}{$\begin{array}{l}\text { Significant } \\
0.01\end{array}$} \\
\hline & & $\begin{array}{l}\text { Traditional } \\
\text { education }\end{array}$ & 19 & 31.16 & 187.3 & & & \\
\hline \multirow[b]{2}{*}{2} & \multirow[b]{2}{*}{$\begin{array}{l}\text { master's } \\
\text { students }\end{array}$} & E-learning & 25 & 24.73 & 210.2 & \multirow[b]{2}{*}{$0.134-$} & \multirow[b]{2}{*}{24} & \multirow[b]{2}{*}{ Non-Significant } \\
\hline & & $\begin{array}{l}\text { Traditional } \\
\text { education }\end{array}$ & 25 & 36.46 & 211.0 & & & \\
\hline
\end{tabular}


The table above shows that:

- There are statistically significant differences between the use of e-learning and traditional education in working with groups and developing skills as a whole for master students in favor of e-learning from the viewpoint of faculty member's significance at (0.01).

- There are no statistically significant differences between the use of elearning and traditional education in working with groups and developing of skills of students of the master stage as a whole in favor of e-learning from the viewpoint of students of the master stage. This indicates that master stage students are not aware of the importance and role of e-learning in developing skills as a whole. Thus we accept the main hypothesis of the study partially, concerning the view of the faculty members and its rejection from the viewpoint of students of the master stage.

\section{Table (7): Significant of the differences between the use of} e-learning and traditional education in working with groups and developing the mental skills for master's students

\begin{tabular}{|c|c|c|c|c|c|c|c|c|}
\hline $\mathrm{S}$ & Category & $\begin{array}{l}\text { Type of } \\
\text { education }\end{array}$ & Sample & (SD) & Mean & $\mathrm{T}$ value & DF & Sig \\
\hline \multirow{2}{*}{1} & \multirow{2}{*}{$\begin{array}{l}\text { faculty } \\
\text { members }\end{array}$} & E-learning & 19 & 6.91 & 89.26 & \multirow{2}{*}{$3.95^{* *}$} & \multirow{2}{*}{18} & \multirow{2}{*}{$\begin{array}{l}\text { Significan } \\
0.01\end{array}$} \\
\hline & & $\begin{array}{l}\text { Traditional } \\
\text { education }\end{array}$ & 19 & 12.7 & 73.26 & & & \\
\hline \multirow{2}{*}{2} & \multirow{2}{*}{$\begin{array}{l}\text { master's } \\
\text { students }\end{array}$} & E-learning & 25 & 11.55 & 80.88 & \multirow{2}{*}{-1.008} & \multirow{2}{*}{24} & \multirow{2}{*}{$\begin{array}{l}\text { Non- } \\
\text { Significan }\end{array}$} \\
\hline & & $\begin{array}{l}\text { Traditional } \\
\text { education }\end{array}$ & 25 & 14.56 & 83.32 & & & \\
\hline
\end{tabular}

** Significance at $(0.01)$

* Significance at (0.05)

The table above shows that:

- There are statistically significant differences between the use of e-learning and traditional education in working with groups and developing mental skills for students of the master's stage in favor of e-learning from the viewpoint of faculty members' significance at (0.01).

- There are no statistically significant differences between the use of e-learning and traditional education in working with groups and developing the mental skills of master stage students in favor of elearning from the perspective of master students. This indicates that master students are not aware of the importance and role of elearning in developing mental skills. 


\begin{tabular}{||cr||}
\hline \multicolumn{2}{|c||}{ The Egyptian Journal of Social Work (EJSW) https://ejsw.journals.ekb.eg/e } \\
ISSN: $2356-9204$ & Vol 11, Issue.1, January2021 \\
\hline
\end{tabular}

Thus, we accept the first hypothesis of the study partially, concerning the view of the faculty members and its rejection from the viewpoint of students of the master stage.

\section{Table (8): Significant of the differences between the use of} e-learning and traditional education in working with groups and developing the professional skills for master's students

\begin{tabular}{|c|c|c|c|c|c|c|c|c|}
\hline S & Category & $\begin{array}{l}\text { Type of } \\
\text { education }\end{array}$ & Sample & (SD) & Mean & $\begin{array}{l}\mathrm{T} \\
\text { value }\end{array}$ & $\mathrm{DF}$ & Sig \\
\hline \multirow[b]{2}{*}{1} & \multirow[b]{2}{*}{$\begin{array}{l}\text { faculty } \\
\text { members }\end{array}$} & E-learning & 19 & 4.30 & 48.05 & \multirow[b]{2}{*}{$* * 4.28$} & \multirow[b]{2}{*}{18} & \multirow[b]{2}{*}{$\begin{array}{l}\text { Significant } \\
0.01\end{array}$} \\
\hline & & $\begin{array}{l}\text { Traditional } \\
\text { education }\end{array}$ & 19 & 7.26 & 40.05 & & & \\
\hline \multirow[b]{2}{*}{2} & \multirow[b]{2}{*}{$\begin{array}{l}\text { master's } \\
\text { students }\end{array}$} & E-learning & 25 & 6.53 & 44.80 & \multirow[b]{2}{*}{0.049} & \multirow[b]{2}{*}{24} & \multirow[b]{2}{*}{$\begin{array}{l}\text { Non- } \\
\text { Significant }\end{array}$} \\
\hline & & $\begin{array}{l}\text { Traditional } \\
\text { education }\end{array}$ & 25 & 8.16 & 44.72 & & & \\
\hline
\end{tabular}

The table above shows that:

- There are statistically significant differences between the use of elearning and traditional education in working with groups and developing professional skills of master stage students in favor of elearning from the viewpoint of faculty members' significance at (0.01).

- There are no statistically significant differences between the use of e-learning and traditional education in working with groups and developing the professional skills of master stage students in favor of e-learning from the perspective of master students. This indicates that master students are not aware of the importance and role of elearning in developing professional skills.

Thus, we accept the second hypothesis of the study partially, concerning the view of the faculty members and its rejection from the viewpoint of students of the master stage.

Table (9): Significant of the differences between the use of e-learning and traditional education in working with groups and developing the general skills for master's students

\begin{tabular}{|c|c|c|c|c|c|c|c|c|}
\hline S & Category & $\begin{array}{l}\text { Type of } \\
\text { education }\end{array}$ & Sample & (SD) & Mean & $\mathrm{T}$ value & $\mathrm{DF}$ & Sig \\
\hline \multirow[b]{2}{*}{1} & \multirow{2}{*}{$\begin{array}{l}\text { faculty } \\
\text { members }\end{array}$} & E-learning & 19 & 6.50 & 87.10 & \multirow[b]{2}{*}{$* * 3.87$} & \multirow[b]{2}{*}{18} & \multirow{2}{*}{$\begin{array}{l}\text { Significan } \\
0.01\end{array}$} \\
\hline & & $\begin{array}{l}\text { Traditional } \\
\text { education }\end{array}$ & 19 & 12.71 & 74.0 & & & \\
\hline \multirow[b]{2}{*}{2} & \multirow[b]{2}{*}{$\begin{array}{l}\text { master's } \\
\text { students }\end{array}$} & E-learning & 25 & 10.06 & 84.56 & \multirow[b]{2}{*}{0.531} & \multirow[b]{2}{*}{24} & \multirow[b]{2}{*}{$\begin{array}{l}\text { Non- } \\
\text { Significant }\end{array}$} \\
\hline & & $\begin{array}{l}\text { Traditional } \\
\text { education }\end{array}$ & 25 & 14.9 & 83.04 & & & \\
\hline
\end{tabular}


The table above shows that:

-There are statistically significant differences between the use of e-learning and traditional education in working with groups and developing general skills of master stage students in favor of elearning from the viewpoint of faculty members' significance at (0.01).

- There are no statistically significant differences between the use of elearning and traditional education in working with groups and developing the general skills of master stage students in favor of elearning from the perspective of master stage students. This indicates that master students are not aware of the importance and role of elearning in developing general skills. Thus, we accept the third hypothesis of the study partially, concerning the view of the faculty members and its rejection from the viewpoint of students of the master stage.

\section{Discussion:}

The current study sought to test the hypothesis where are statistically significant differences between the use of e-learning and traditional education in working with groups and developing of skills as a whole for masters students in favor of e-learning from the viewpoint of faculty members, this shows the effectiveness and importance of e-learning in developing skills in general among masters students in particular and university education in general, which was confirmed by a study (Al-Hammadi, 2011) as it aimed at the role of e-learning in university education in terms of "skills, requirements, and obstacles", the results of this study are consistent with the results of scientific research in activating the importance of E-learning in university stages.

Furthermore, there are statistically significant differences between the use of e-learning and traditional education in working with groups and developing mental skills for students of the master stage in favor of e-learning from the viewpoint of faculty members. This indicates the importance of using e-learning to develop mental skills among master students and agree with the study (Jami, 2009) where she clarified the importance of e-learning and the models and strategies for using it. This study is consistent with the results of research in developing students' skills through specific models and strategies.

In addition, there are statistically significant differences between the use of e-learning and traditional education in working with groups and developing professional skills of master stage 
students in favor of e-learning from the viewpoint of faculty members. This indicates the importance of e-learning in developing the professional skills of the master stage students, and this agrees with the study (Majlakh, 2017) as it aimed to know the role that e-learning grants to human resources in the institution as a training method based mainly on electronic media and communication networks as well as the skills acquisition and organizational knowledge acquisition in the institution, that is, it helps automatically determine the training needs imposed by the competition environment. The results of this study are consistent with the research results to clarify the importance of elearning in the acquisition of skills.

Also, there are statistically significant differences between the use of e-learning and traditional education in working with groups and developing general skills of master stage students in favor of elearning from the viewpoint of faculty members. This indicates the importance of using e-learning to develop general skills among master stage students, and this agrees with the study (Ahmed\& Dendrawi, 2012) as it aimed to identify the viewpoint of faculty members and their assistants in activating e-learning and emphasizing the necessity of activating e-learning and its importance where the results of the study agree with the results of scientific research in the viewpoint of the faculty members in confirming the activation of e-learning.

Statistical procedures used in the study, the data were processed by computer using the program (spss.v. 24.0) Statistical Packages for Social Sciences, and the following statistical methods were applied:

Frequencies and percentage were used to describe the characteristics of the study population.

1- Arithmetic average was used to judge the level of using e-learning in working with groups and developing the skills of master stage students, so that the beginning and the end of the five-point scale categories, totally agree $=5$ degrees, agree $=4$ degrees, almost Agree $=3$ degrees, not agree $=2$ degree, not totally agree $=1$, the data have been coded and entered in to the computer.

2- Accounting index was used if the phrases are equal in the arithmetic mean, the phrase that indicates the sentence that fails to rank higher.

3- Range was calculated by the difference between the greatest value and the lowest value.

4- Test ( $t$ ), this is contrast between two quantitative variables (test the study hypotheses) 
The Egyptian Journal of Social Work (EJSW) https://ejsw.journals.ekb.eg/e

ISSN: 2356-9204

Vol 11, Issue.1, January2021

\section{Recommendations:}

The current study recommends:

1- Much more attention should be paid to activate the use of e-learning for master students in all educational courses.

2- The necessity of holding electronic training courses to develop the skills of master's students.

3- The necessity of educating master's students about the importance of e-learning and its requirements.

4- The necessity to overcome the obstacles faced by master students when using e-learning and work to solve them.

5- The necessity of providing communication devices and information services to implement e-learning effectively.

\section{References:}

Ahmed Aref, Hanaa \& Dendrawy, Said Mohamed (2012). A proposed program to activate the mechanisms of e-learning in the university field from the perspective of the method to social group work: international scientific conference, 25, no.1, faculty of social work, Helwan University, pp. 211-273.

Al-Chadian, bin Abdul Razek Abdul Mohsen (2012). E-learning challenges and difficulties and ways to overcome them, Journal of educational and Social studies: vol.18, no 4, Saudi, dar almandumah, pp. 423- 454.

Alcomeshi, Ali Lutfia (2016). E-learning.the pillar of the knowledge society: Journal of the generation of humanities and social sciences, no 24, Saudi, Generation Center for Scientific Research, pp. 141-152.

Al-Hammadi, Bint Saleh Faiza (2011). University e-learning Requirements Skills and Constraints: Journal of the College of Education, vol.22, no 86, Banha University, pp. 80-114.

Al-maser, aqeel Hind (2014). Measuring Female attitudes towards using e-learning in teaching social work: Literature Journal, vol.26, no.2, college of Literature, King Saud University, pp. 243- 282.

Al-Saqer, Mohammed Abdullah (2012). a proposed vision for the application of elearning at Al-Kharj University: Journal of the College of Education, vol.28, no.1, Assiut University, pp .153-189.

Al-Sinhouri, Muhammad Ahmad (2007). Encyclopedia of the advanced general practice curriculum for social service and the challenges of the twenty-first century: third part, Cairo, Arab Renaissance dar.

Al-Turk, Mohammed Khalid (2019). The shift from traditional education to elearning, Sirte University: Journal of Science and Humanities, Vol 9, N 1, pp. $22-40$.

Al-Obaidi, Qasim (2015). Virtual education: reality and ambition, Jordan, Philadelphia University.

Bartley\& Golek (2004). Evaluating the cost effectiveness of online and face-to-face instruction educational technology\& society, college of business administration: university of Tennessee, vol. (7), no. (4).

Barker, Jamie \&Turner, martin (2014). The mental skills handbook for athletes, amazon books, United States, ProQuest.

D. johnson, Scott \& R. Aragon, Steven (2002). The influence of learning style preferences on student success in on line versus face to face environment: The 
The Egyptian Journal of Social Work (EJSW) https://ejsw.journals.ekb.eg/e

ISSN: 2356-9204

Vol 11, Issue.1, January2021

American journal of distance education Lawrence urban associates, inc, pp. 227-252.

Elgamal, Sarah (2014). An investigation of electronic learning in higher education: doctoral thesis, Northumbria University.

Erba, Sidney., Kay L. Schlozman \& Henry Brady (1995). Voice and Equality: Civic Voluntarism in American Politics, Cambridge, MA, Harvard University Press.

Habib, Shehata Jamal (2009). General practice a modern perspective on social work: Alexandria, the modern university office.

Hamida, Ammar Zineb (2015). E-Learning: Law and Humanities Journal, no, (23), Djelfa, Rayan Ashour University.

Hassan, Mohamed Shawky (2009). E-training and human resource development. E-learning magazine, vol. 4. Egypt, Mansoura University. p. 140.

Hussein, Ahmed Ali (2003), a glossary of educational terms defined in curricula and teaching methods, Cairo, The world of books.

Mahdi, Al-Arabawi Amal (2006). Adult education in the light of the philosophy of distance education "university as a model": the first annual conference of the Arab Center for Education and Development in cooperation with Ain Shams University, part 1, Alexandria, Modern university office, pp. 65-90.

Malakhleh, Salim (2017). E-learning as an effective tool in training and managing knowledge of human resources: humanities Journal, vol.2, no 7, al-arabi Bin mahidi university, Algeria, pp. 534-552.

Rahooma, M. A (2002). Cybernetics Sociology: Kuwait, National Council for Culture, Arts.

Mohsen, Ali \& Muhammad Ratib, Basem (2014). Attitudes of the academic supervisors at al-quads Open University in Palestine towards the uses of the net in education: Palestine, al-quads Open University.

Oledzki, R. Marek (2005). An investigation in to the use of multimedia for electronic learning: master thesis, Nottingham Trent University, United States, proquest.

Othman, Mukhtar Khalid (2017). Traditional education has its pros and cons: Malaysia, University of technology.

Robyn, Benson \& Samara wickrema, Gayni (2004). Helping academic staff to design electronic learning and teaching approaches: British journal of education technology, vol (35), issue 5, and pp.214-240.

Shehata Hassan \& Al-Najjar Zainab (2003). A Dictionary of educational and Psychological terms: Cairo, the Egyptian Dar.

Robbins, S. P \& Singer, J. B (2014). From the editor the medium is the message: Integrating social media and social work education. Journal of Social Work Education, Vol50, N3, pp.387-420

Todeschini, J. Robert (2009)

- Implementation of electronic learning within campus institutions of higher learning: PhD thesis, Capella University, United States, ProQuest.

Won, Kevin (2019). Mastering mental and technical skills, amazon books, United States, proquest. 